\title{
Economical assessment of medicinal plants market concentration and monopolization level in Ukraine
}

\author{
Tetiana Mirzoieva ${ }^{1, *}$, Violeta Heraimovych ${ }^{1}$, Iryna Humeniuk $^{2}$, Olga Tomashevska ${ }^{1}$, and \\ Olena Cherednichenko ${ }^{1}$ \\ ${ }^{1}$ National University of Life and Enviromental Sciences of Ukraine, Ukraine \\ ${ }^{2}$ Podilsky Special Education and Rehabilitation Socio-Economic College, Ukraine
}

\begin{abstract}
The article presents a study of today's market of medicinal plants in Ukraine. It was discovered that the world's demand for both medicinal plants and herbal medicines is rapidly growing.Today production of medicinal plants is a promising and profitable activity. The purpose of the article is to research the level of concentration and to determine the leading medicinal plant growers in Ukraine, as well as to assess risks of collective monopolization of Ukrainian medicinal plants market. Object of the research $-\mathrm{a}$ pool of enterprises-producers of medicinal plants in Ukraine, according to official statistics. The assessment of medicinal plants market concentration was carried out using the following coefficients (indices): concentrationratio, Linda Index, Herfindahl-Hirschman Index, relative concentration, entropy index, market share dispersion among leading firms, variation index, Gini index, HallTideman index. In order to clearly demonstrate the level of uneven distribution of medicinal plants in the market between the leading producers Lorenz Curvewas built. The assessment of Ukrainian medicinal plants market concentration and monopolization showed the signs of limited oligopolypresence. The analysis of oligopolynucleus dispersity, which determines the ratio between the sizesof individual firmscomposing it, showed the uneven distribution of market shares between enterprisescompetitors. Further detailed research of the medicinal plants market will make an important contribution tothe market strategy development of this sphere in Ukraine.
\end{abstract}

\section{Introduction}

Today about $30 \%$ of the territory of Ukraine are the landscovered by either wild or partly wild natural flora.The vegetal composition represent a wide range of species including medical, oil, melliferous and other types of plants. Ukraine's forests are rich in berries (wild strawberries, raspberries, blackberries, etc.), mushrooms, wild fruit tries and medicinal

\footnotetext{
*Corresponding author: mirzoeva2018@ukr.net
} 
herbs. The main areas of their gatheringare some areas of Marshy Woodlands or Polissya, Forest-steppe and the Carpathians.

Ukraine is rich in medicinal herbs such as setwell, wild rose, viola tricolor, dandelion, periwinkle, marjoram, wild strawberries, chamomile, black currant,wild blueberry, raspberry, cranberry, lavender, mint, melissa, centaurium, nettle, celandine, St. John's wort, plantain, buckthorn, chicory, bearberry, knot-grass, lily of the valley and many others. Some of these medicinal plants are listed in the Red Book. Most of them grow naturaly, while a huge part is cultivated.About 25 thousand tons of birch sap, 150 tons of marketable honey, more than 7 thousand tons of dry mushrooms, 7 thousand tons of wild berries and fruits, as well as more than 5 thousand tons of medicinal plants are annualy gathered recent yearsin Ukraine's forests (A. Ivchenko, 2019).

Market of medicinal plants in Ukraine is barely studied. Although it is clear that this market is very narrow and unstable. According to different estimates between 109 and 3000 companies and small businesses producing, harvesting and processing medicinal plants operate in Ukraine. As market research show, most of them purchase raw materials from the local people. Moreover, now significant part of the medicinal plants in Ukraine are grown on private plots.Despite the great social and economicalimportanceandfuture prospects of medicinal plants farming, todayboth the industry development in general and business activity of enterprises in this sphere in Ukraine face a number of problems. The main problems are the lack of specialized equipment, quality sowing seed and qualified labour, high labor intensity of production, volatile and unpredictable prices,as well as many others. Existing problems, in return, put negative impact on the market - lowering profitability of medicinal plants production recent years in Ukraine and dropping its volume. During the study it is revealed that in Ukraine over the past 20 years the medicinal plants cultivation area is reduced almost by 6 times, the production of essential oils fell by nearly three times and the quality of special food products based on medicinal plantshave noticeably deteriorated.Pending range of problems that hinder the development of medicinal crop farming growth urges the necessity formedicinal plants market research to be carried out and the branch development strategy to be formed. Today, the absence of well-focused coherent strategy of medicinal plant farming development on a national level causes raw material demandinstability as well as problems to sellboth raw material and final productin Ukraine.

Experts estimate that recent years the shares of wild and cultivated vegetative raw material used for further processing in Ukraine are 50:50. In European countries the share of cultivated raw material reaches as high as $80-90 \%$. At the same time, current trend shows that European producers tend to quit producing medicinal plants. They shift more and more their purchasing demand into developing countries. Accordingly, today's demand for Ukrainian high-quality medicinal plant raw material greatly overwhelms the existing supply. Although some agricultural firms are beginning to grow medicinal plants, it does not really compensate the deficit. Operatorsof Ukrainian market note that there is a necessity to increase the amount of medicinal plant based raw materials production at least twice. This necessity increase goes in line with the global medicinal plants market development trends.

Despite the fact that the leading countries are gradually reducing the volumes of medicinal plantsproduction, this activity remains financially powerful. The total value of all medicinal plants that are used in various industries and sectors of world's economy is 80 billion dollars of the United States. Besides, according to indicators of CAGR (Compound Annual Growth Rate (annual growth rate in the complex percentage) the market volume could grow by $14.88 \%$ and reach $\$ 7$ trillion by 2050 (2018). Thebiggest markets for medicinal plants are China, France, Germany, Italy, Japan, Spain, Britain and the United States. Japan is the world's largest consumer of natural drugs per capita. In China the 
market volume of traditional herbal remedies doubles every 5-6 years, while their own land resources arenearly exhausted. According to HealthNet expert estimates (2019) export of medicinal plants into China may bring more than $\$ 100$ billion per year till 2035. Also analysts admit that the market of herbal remedies at the end of 2023 will grow to $\$ 111$ billion. and this market will annually grow on average by $7.2 \%$ over the 2017-2023. According to the World Health Organization (2019) the world's annual demand for the medicines based on vegetable raw materialswill probably growits value from $\$ 14$ billion now to $\$ 5$ trillion in 2050 .

One of the incentives of the medicinal plants market development is a huge demand for vegetable based medical raw materials from pharmaceutical companies in Ukraine as well as in many other countries. This is caused by the fact that significant share of drugsnow is vegetable based. In this regard, Nikitiuk, Y. (2016) considers the ability to produce significant volumes of ecologically clean raw materials of vegetable origin to be the main competitive advantage of Ukrainian medicinal plants market, as this is a key requirement of the pharmaceutical industry.

Basing on the fact that the medicinalvegetable material production is a significant production areaof world's economy today, there is a necessityto studycurrent market of medicinal plants in Ukraine. It is particularly important to determine the inclination of the main medicinal plants market players to have corporate collusions that: 1) allow them to set aninfluenceupon othercompanies of the segment; 2) give them additional opportunities to manipulate the price in order to obtain greater profits.

\section{Literature review}

Theoretical and practical principles of medicinal plants production development are highlighted in the papers of many Ukrainian scientists. For example, Tkachova, Ye. (2018) notes that in Ukraine Good Agricultural and Collection Practices(GACP) standard for medicinal plants is introduced in 2012, which enables the processors to purchase medicinal plant based raw materials of the stable high quality. The principles and rules of Good Manufacturing Practices(GMP) for medicinal products setting the requirements of standardization of medicinal plant based raw materials and their basic quality parametersare also applicable.Studying the market of medicinal plants Nikitiuk, Yu. (2016) distinguishes its characteristic features: medicinal plant based raw materials market is not saturatedyet; the existing offer does not satisfy neither domestic nor foreign demand; favorable natural, ecological and economical conditions for cultivation of medicinal plants, etc. Drebot, O. and Solohub, Yu. (2018), studying the world's experience of medicinal plants production, found that global trends in the health care system paradigm changesraising more attention towards natural medicinal products open new perspectives for the sphere of medicinal plants production.

The problematics of medicinal plants production were also studied by the scientists from all continents. All researchers in their works emphasize the importance of medicinal plants productionin the present conditions and the necessity for its further development. Thus, the Indian scientists from the Institute of Research and Development of Medicinal Plants Chandra P. Kuniyal, Pramod C. Kuniyal, Jitendra S. Butola \& Rakesh C. Sundriyal (2013) note that the mass cultivation of various types of medicinal plants can lead to significant economical benefits.

Mafimisebi, T. (2013), exploring the international market for medicinal plants and their processing products in general and African in particular, notes that it is very large. For example, in Egypt medicinal and aromatic plants are a significant source of national income. The cultivationarea of these plants is constantly growing. Owing to the cheap labor and the ability to harvest several crops in one year Egypt became the world largest supplier 
of chamomile and calendula. Another 50 species of medicinal plants cultivated in Egypt also have economic value to contribute countrie's exports.

In addition, products of medicinal plants processing penetrate into new market segments as vegetative components of healthy food and preventive means. Existing data show that in different regions of the world market of medicinal plants processing products grows on average 3-4 times as fastas the national economies in the same regions do. The increase of trade, which in some cases reaches $20 \%$, means that the market size of the medicinal plants and the products of their processing doubles every 4-5 years.

American scientists Jeanine M. Davis and Richard, E. (2019), whose studies relate to the industry of medicinal plants, note that the medicinal products and aromatherapeutic means based on vegetativematerials are the category of sales which has the highest growth rate in Today's world.

European scientists Lucy Hoareau and Edgar J DaSilva. (1999) point out that traditionally in Europe, particularly in such countries as Albania, Bulgaria, Croatia, France, Germany, Hungary, Poland, Spain, United Kingdom there are about 1500 species of medicinal and aromatic plants that are used very widely. According to the last survey conducted in the EU member states, around 1400 plant based formulationsare widely used. Besides, these medicines are popular and play important role in a primary healthcare in Belgium, France, Germany and the Netherlands.

Chapman, K. And Chomchalow, N. (2005) indicate that an important role today medicinal plants play in Asian countries - both in highly developed and emerging economies. In many Asian countries, they give income to people who earn their living by selling medicinal plants, which they either cultivate or gather. Due to the constantly growing demand for medicinal plants some Asian countries have attempted a large-scale cultivation of certain species.

In addition to the economic feasibility the medicinal plants production, threre is another aspectof its importance: the fact that it contributes to the preservation of biological diversity on the planet. So, Lange, D, (2000). notes that the medicinal and aromatic plants suit very well for the purposes ofimplementation of the objectives of Convention on Biological Diversity.

A brief literature review shows that the production of medicinal plants in the modern world is promising and profitable activity. In this regard, its development in Ukraine looks very expedient. The purpose of the article is to research the medicinal plants production concentration level, determine the branch leaders in Ukraine, as well as toassess risk of group monopolization of the Ukrainian medicinal plantsmarket.

\section{Methodology}

Within the framework of this study mainly the secondary data from such sources as books, articles in periodicals, publications in the Internet sources and statistical information were used. Statistical datafor our analysis has been received from the State Statistics Service of Ukraine. As for the methods, the study is based on the use of a systemic approach. In particular, by means of statistic-economical and economic-mathematical methods, comparative analysis, index and analytical methods of the indicators interpretation the oligopoly nucleuspresent on the Ukrainian medicinal plants market was revealed.

\section{Results and discussion}

A characteristic feature of medicinal plant production is the ability to grow a wide range of medicinal crops. In particular they can be classified as follows: 
1) wild natural medicinal plants;

2) medicinal plants insufficiently available in a wild nature and cultivated to meet the needs of the pharmaceutical industry;

3) medicinal plants that are exclusively cultivated;

4) agricultural medicinal plants;

5) cultivated medicinal plants can be divided into field crops, greenhouse-field crops, greenhouse crops, and variety selection crops.

According to the World Health Organization classification system medicinal plants comprise three groups: 1) those, which are used for treatment directly; 2) those, which are used for the production of Galen Preparations (including home-made); 3) raw materials for industrial processing or for the production of biologically active products, which are subsequently used for the production of medicines. A wide range of medicinal plants and a wide range of their application form the potential of cost-effective diversified production. And, despite the fact that world market economy has a high level of competition in a given sector, Ukrainian medicinal plant production could rather be described as the sector with an absence or a very low level ofcompetition.

Within this research we operated with the data of the State Statistics Service of Ukraine, according to which the main shareof medicinal plants sold in 2018 was traded by 19 companies. This pool of large specialized enterprises formed so-called core of Ukrainian medicinal plants production. As seenfrom the analysis of Fig. 1, the majority of 2018 Ukrainian medicinal plants production, namely $68.7 \%$, was traded by three biggest firms.

This fact indicates the presence of monopolistic trends in the sphere of medicinal plants production. The experts, who point out that today's medicinal plants market is very volatile, and there is no industrial competition in the market, also confirm this statement.Only a very small percentage of farms specialize on cultivation of medicinal plants, that is why the industry has to import significant amounts of raw materials from other origins.

During the study it is revealed that the Ukrainian medicinal plants production and crude drug materialprocessing market is called a closed space. Stepanushko, 1. (2019) notes that most market players hereknow each other, they all know who and how much produces and consumes and what reputation each one has. A characteristic feature of modern medicinal plants production sphere in Ukraine is that production of several medicinal crops is gradually growing to the industrial level. In particular, the study results show that Ukrainian producers are finding their interest in the cultivation of lavender, marigolds, plantain, dandelion, sage, thyme, etc. These spieces, until recently, were not grown on the territory of Ukraine at all,were grown in small amounts or some of them were not present as they requireddifferent climatic conditions. But as a result of global warming there is a possibilityto cultivate them in Ukraine now. 


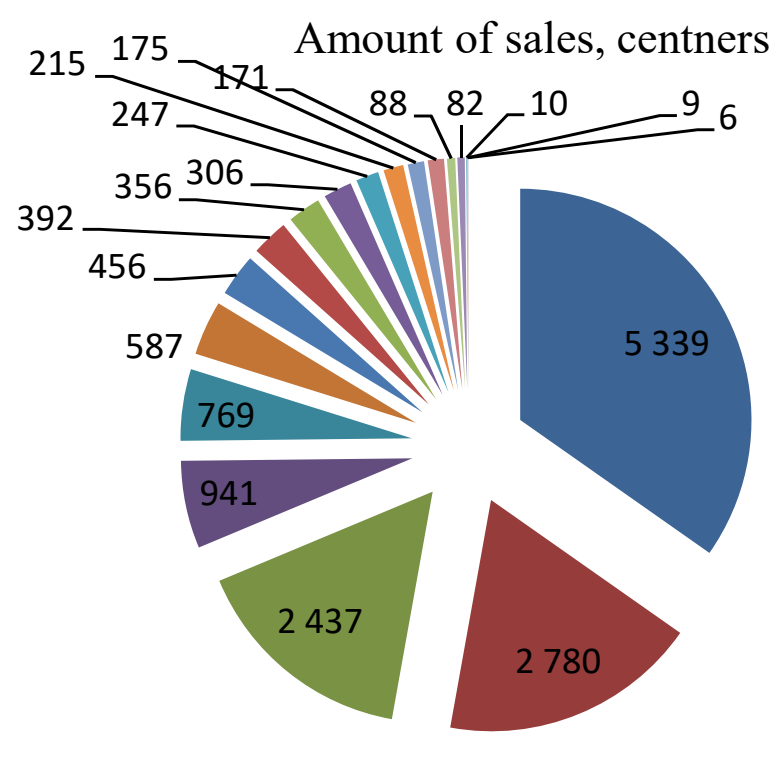

Fig. 1. Sales of medicinal plants by companies, Ukraine (2018). Source: Developed by the authors using the data from the State Statistics Service of Ukraine.

In general, owing to its natural-climatic conditions Ukraine has the potential to become one of Europe's biggest producers of high-quality medicinal raw materials for pharmaceutical, cosmetic, perfumery, food and other industry sectors. Although, today Ukraine with its huge potential is only ranked 44 among the global exporters ofmedicinal plant based products.

At the same time, monopolization trends persisting on Ukrainian medicinal plants marketcreate risks of industry monopolization, which may significantly inhibit its development. Today's reality of Ukrainian market is that the majority of small producers are unable to compete with the big producers of medicinal plants - neither in terms of amounts, nor in terms of quality.

The formation of an effective competitive environment in the sphere of medicinal plants production is complicated by the fact that the demand for medicinal plants is volatile and constantly changing. Tkachova, Ye. (2018) notes that it does not only depend on the purchasing requests from the buyerss, but also on the shelf life of the raw material. The fact that the use of medicinal plants depends on the characteristics of biologically active chemical constituents of each plant. The content of these biologically active constituents in plants as a whole and in different plant parts is impermanent and depends on the conditions of cultivation, time of day, weather conditions and a number of other important factors.In addition, we have to take into account that most of the biologically active constituentsare very perishable. Many of these perishable plant constituentsare easily destriyed: they quickly evaporate, decompose at high temperatures and under the sunlight. Precipitation even in such a small amount like dew can wash soluble substances off the aboveground plant organs. Underestimation of any factor can lead to the fact that the amount of active ckemical constituent in the harvested or gathered crude drug material would be to low, which in turn affects its marketability.

To study the risk of medicinal plants market further monopolization and the anticompetitive actions occurrence the assessment of production concentration level in this area was conducted during the reserch. The objectives of this assessment were to 
characterize the level of non-uniformity of medicinal plants production and sales distribution between the companies and the possible impact of each of them upon the medicinal plants circulation conditions. Assessment of a specific market concentration requires the application of the following coefficients (indices): concentration ratio, Linda Index, Herfindahl-Hirschman Index, relative concentration, entropy index, market share dispersion among leading firms, variation index, GiniIndex, Hall-Tideman Indexand others. (Pervakov, 2009).

Mainly in order to measure the concentration of a certain market share a method of calculation of the fixed number of firms in a particular market is applied usingdifferent indexes of concentration. Within this study, the following concentration indexeswere calculated: Herfindahl-Hirschman Indexand Hall-Tideman Index, as well as such indicators as the dispersion of market shares, coefficient of variation, coefficient of entropy,coefficient of relative entropy (see Table 1).

Under the present conditions a number of companies including quite lots of large firms operatein many markets. But not all the big businesses pose the same effect on the market. In order to study the degree of dominance of Ukrainian medicinal plants market largest participants the stiffness of its oligopolynucleuswas determined, as long as the harder this stiffness is the more opportunity for the coordinated supercompetitiemarket behaviour.

Table 1. Indexes of concentration of medicinal plants market in Ukraine in 2018*.

\begin{tabular}{|c|c|}
\hline Indicator & Value \\
\hline Herfindahl-Hirschman Index & 3785 \\
\hline Hall-Tideman Index & 0,408 \\
\hline Dispersion of market shares & 150,4 \\
\hline Coefficient of variation & 4,51 \\
\hline Coefficient of entropy & 0,969 \\
\hline Coefficient of relative entropy & 0,882 \\
\hline
\end{tabular}

* calculated by the authors

We used LindaIndex, which is applied to assess the relative strength of the influence of market leaders in comparison with other large and small enterprises operating on the same particular market. Linda Index is mostly used within the European Community to evaluate the behavior of the most influential economic entities among the largest sellers on a certain market. In GeneralLinda indexis a tool for determining oligopoly «limits» and is calculated by the formula:

$$
\mathrm{L}=\frac{1}{\mathrm{~K} K-1)} \times \sum_{\mathrm{i}=1}^{\mathrm{k}} \mathrm{Q}_{\mathrm{i}}
$$

where $k$ - the number of significant marketoperators; $Q_{i}$ - the ratio between the average marketshares and the entitiesand $k+1$ entities; $i$ - the number of leading businesses among $k$ significant entities (Valitov, 2006).

$$
Q_{i}=\frac{S_{i}}{i}+\left(\frac{S_{k}-S_{i}}{K-i}\right)
$$

where $S_{i}$ - total market share of $i$ economic entities; $S_{k}$ - market share of k significant entities (Valitov, p. 2006).

Linda index is calculated step by step: first for the two largest enterprises, then for the three, and so on till a continuity violation of the decrease in L parameter is obtained, that is, until the result $\mathrm{L} \mathrm{L} \mathrm{k} \mathrm{k}>-1$. Breach of continuity indicates that the company added to the last calculation has a significantly smaller market share than any of the previous ones 
(Okrepsky, R. and Migal, O. 2016). The study of the oligopoly nucleus stiffness in the medicinal plants market using the Linda index is presented in Table. 2.

According to the calculations, continuity breach appears when $\mathrm{k}=4$ (L4 > L3), therefore, oligopolyis createdby the first 3 firms by theirmarket share, which account for $68.7 \%$ of sales. The nature of such an oligopoly is defined as "stiff". It is worth noting that oligopoly is one of the most common structures in the modern economy. As a rule, oligopoly is more inherent in the technically complex branches of national economies of different countries of the world - metallurgy, chemistry, car-building, electronics, shipbuilding and aircraft-building.

Given that the branch of medicinal plant production is not that complex, but at the same time it is very specific one, the presence of oligopoly in this field is natural. Zadoya A. (2000) notes that there are typically between two and ten businesses operating in oligopolistic markets, accounting for half or more of total product sales.

Table 2. The calculation of the Linda index for medicinal plants market in 2018 (developed by the authors according to the data in Fig. 1).

\begin{tabular}{|c|c|c|c|c|c|c|c|c|c|}
\hline$k$ & $Q 1$ & $Q 2$ & $Q 3$ & $Q 4$ & $Q 5$ & $Q 6$ & $Q 7$ & $Q 8$ & $L_{k}$ \\
\hline 2 & 1,921 & & & & & & & & 0,960 \\
\hline 3 & 2,047 & 1,666 & & & & & & & 0,619 \\
\hline 4 & 2,601 & 2,403 & 3,739 & & & & & & 0,729 \\
\hline 5 & 3,083 & 2,937 & 4,115 & 3,738 & & & & & 0,694 \\
\hline 6 & 3,553 & 3,430 & 4,596 & 4,239 & 4,1792 & & & & 0,667 \\
\hline 7 & 4,019 & 3,911 & 5,112 & 4,759 & 4,704 & 4,698 & & & 0,648 \\
\hline 8 & 4,469 & 4,363 & 5,594 & 5,216 & 5,129 & 5,052 & 4,993 & & 0,622 \\
\hline 9 & 4,899 & 4,786 & 6,030 & 5,614 & 5,479 & 5,338 & 5,233 & 4,936 & 0,588 \\
\hline
\end{tabular}

This, of course, makes businesses dependent on each other. Every business in the industry is aware that a change in a product price or production volume will trigger the response of its competitors. This is what is typical for the Ukrainian market of medicinal plants. The study revealed that dramatic collapse of the price for a particular crop is possibleeven if only one large producer completely closes demand for it.

Significant in the framework of further analysis will be the study of the oligopoly nucleus dispersion. As even in a highly concentrated market there can be an active competition due to the even distribution of shares and even size of individual entities that make up its composition. In order to study the oligopoly nucleus dispersion, the share of each of the leading companies in the oligopoly nucleus in Ukrainian medicinal plants market was calculated (Table 3). The results obtained allow us to determine the evenness of market shares distribution among the competing companies listed in the Table 4 . This in its turn makes it possible to assess the risks of collective monopolization, which is the achievement of dominant market leadership through coordinatedmarket behavior of the leading companies. For this purpose, we use a generic indicator - the coefficient of Herfindahl-Hirschman (HHI), calculated by the formula (Volkov, V. and Goroshkova, L. 2012).

$$
H F I=\sum_{i=1}^{h} s_{i}^{2},
$$

The calculation of the shares of the companies belonging to the oligopoly nucleus makes it possible to emphasize the importance of the largest entity in the totality. Peteshova, T. (2011) notes that the market is considered unconcentrated if the $\mathrm{HHI}<1000$, moderately concentrated if the $\mathrm{HHI}<1800$ and highly concentrated if the HHI $>1800$. 
Table 3. Calculation of shares of enterprises forming to the oligopoly nucleus of medicinal plants market in 2018 (developed by the author basing on the dafa of Fig. 1).

\begin{tabular}{|c|c|c|}
\hline Company Rank & Market share, $\%$ & Share in the oligopoly nucleus, $\%$ \\
\hline 1 & 34,7 & 50,6 \\
\hline 2 & 18,1 & 26,3 \\
\hline 3 & 15,9 & 23,1 \\
\hline
\end{tabular}

In the case where the index value is in the range from 1225 to 3400 , the market is called limited oligopoly, from 3400 to 10000 - the market with a dominant firm. That is, the higher the value of the Herfindahl-Hirschman index, the higher the concentration of sellers in a given market, and vice versa, the smaller the values of the Herfindahl-Hirschman index, the greater the competition in the market is, and the lower the concentration and market power of enterprises are.

The Hall-Tidman Index or Rosenbluth Index (IR) is also used to determine the degree of market concentration. It reflects the number of competitors, the share of each of them in the total amount of sales and the rank of these shares. It is calculated on the basis of comparison of ranks of enterprises of a certain market:

$$
I_{n}=\frac{1}{2 \sum_{i=1}^{n} i s_{i}-1}
$$

where $\mathrm{i}$ - is the rank of the enterprise share from maximum to minimum. The maximum value of the Hall-Tidman index is one (under monopoly conditions) (Zaitseva, N. 2011). The minimum is $1 / \mathrm{N}$, where $\mathrm{N}$ is the number of businesses in the industry. The advantage of the Holl-Tidman Index is the ability to rank enterprises in terms of importance, which contributes to a deeper analysis of a particular industry. The disadvantage, as noted by Gornyak, V. and Filipovich, V. (2012) is that this index cannot be calculated completely at a certain point in time, it is necessary to consider it in dynamics.

In order to evaluate the possible market power of enterprises, given the inequality of their size, they use the market share adispersion indicator. This indicator reflects the degree of uneven distribution of enterprise shares in a particular market and is calculated by the formula:

$$
a^{2}=\frac{1}{n} \sum_{i=1}^{n}\left(S_{i}-\bar{S}^{2}\right.
$$

where $\sigma-$ is the root mean square deviation of the enterprise market shares; $S_{i}$ is the share of the $\mathrm{i}$-th enterprise in the market; $\mathrm{S}$ - the average market share of the enterprise; $\mathrm{n}$ is the number of enterprises (Volkov, V. and Goroshkova, L. 2012).

In addition, Peteshova, T. (2011) notes that the coefficient of variation is also used to estimate the evenness of the distribution of production and sales between market-leading enterprises. It is calculated by the formula:

$$
V=a: \bar{S},
$$

More uneven distribution of enterprise shares corresponds to the higher values of dispersion and variation indicators.

The indices calculated above measure directly the concentration while they only allow to assess market competitionindirectly. Concentration means that the market is governed by certain rules established by large enterprises. At the same time, competition is characterized by "disorder" movement of enterprises and market entropy. In this regard, entropy 
indicators can be used to directly measure the degree of competition. The entropy coefficient is used to estimate the degree of market disorder. Volkov, V. and Goroshkova, L. (2012) say that it is the sum of market member companies sale shares, weighted by the natural logarithm of its inverse value:

$$
E=\sum_{i=1}^{n} s_{i} \ln \frac{1}{S_{i}}
$$

The entropy value ranges from 0 to 1 . The higher its value is, the higher is the level of competition in the market. Along with this factor, the relative entropy index (E0) is calculated [2].

$$
E_{0}=\frac{E}{l_{(n)}}
$$

Table 4. Calculation of indexes of medicinal plants market concentration in Ukraine in 2017 (calculated by the authors according to data from table 3).

\begin{tabular}{|c|c|}
\hline Indicator & Value \\
\hline Herfindahl-Hirschman Index & 3785 \\
\hline Hall-Tideman Index & 0,408 \\
\hline Dispersion of market shares & 150,4 \\
\hline Coefficient of variation & 4,51 \\
\hline Coefficient of entropy & 0,969 \\
\hline Coefficient of relative entropy & 0,882 \\
\hline
\end{tabular}

The actual value of the Herfindahl-Hirschman index, received as a result of our calculations, indicates that a limited oligopoly has been established in the Ukrainian medicinal plants market. The Hall-Tidman (Rosenbluth) Index, which takes into account the ratio between the size of the enterprises, is quite low (the minimum level for the surveyed group of enterprises is 0.143 ), which indicates the limited market power of businesses. The high value of the market share dispersion and the coefficient of variation is explained by the significant gap between the market share of the largest producer and the other competitors. The same circumstance explains the level of entropy and relative entropy coefficients, which measure the uneven distribution of market shares between economic entities. The lower the value of these indicators is, the greater ability to influence the market price sellers have.

It is possible to visualize more clearly the degree of uneven distribution of a certain market between the main producers by using the Lorentz curve image. In this case, the area bounded between the actual Lorentz curve and absolutely uniform distribution curve shows the degree of unevenness of the enterprise shares. The larger convexity of the Lorentz curve and the distance from the bisector correspond to the higher market concentration and vice versa (Figure2). As seen from the figure, the actual Lorentz curve deviates from the line of even distribution. This means that there is a difference in market shares for the enterprise totalitybeing studied.

A mathematical indicator of the uneven distribution of a particular market is the Gini index or coefficient $(\mathrm{G})$. It allows you to determine how evenly a variable is distributed among market participants. The value of the Gini coefficient ranges from zero to one. If the coefficient counts zero, the market can be describedas absolute equality, and if it counts one - absolute inequality. The higher is the value of the coefficient, ie, the closer it gets to one, the greater is the differentiation ofmarket distribution between the individual producers. 
The calculation of this index for the set of companies belonging to the oligopoly nucleus of the medicinal plants market is done by the formula:

$$
G=\frac{1}{n}\left(n+1-2\left(\frac{\sum_{i=1}^{n}\left(n+1-i j y_{i}\right.}{\sum_{i=1} y_{i}}\right)\right),
$$

where $n$ is the number of enterprises in the totality; $y_{i}$ is the market share of the $i$-th enterprise.

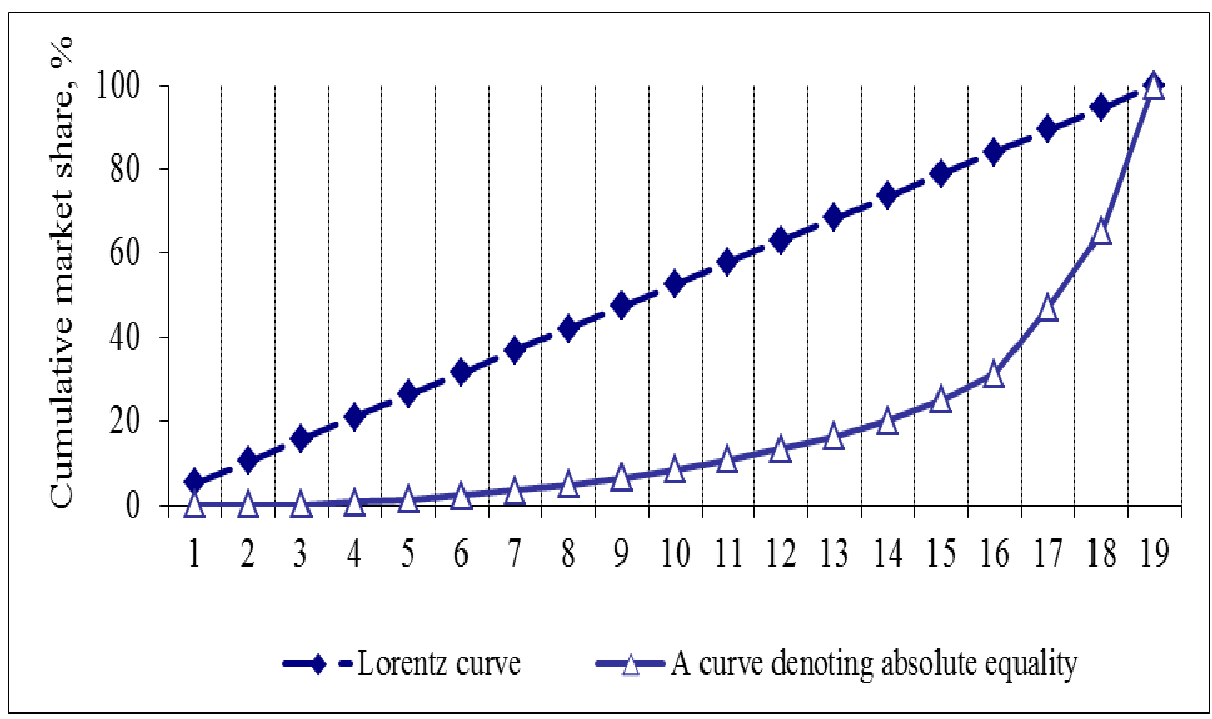

Fig. 2. Lorentz curve for the enterprises belonging to the oligopoly nucleus of Ukrainian medicinal plants market (developed by the author according to the data from Table. 4). Source: Developed by the authors using the data from the State Statistics Service of Ukraine.

The obtained value of the Gini index $(0,183276)$ confirms the existence of unevenness of the studied market distribution among its participants, which increases the likelihood of the competition decrease and market monopolization increase tendency appearance.

\section{Conclusion}

The conducted assessment of Ukrainian medicinal plants market concentration and monopolization made it possible to identify the presence of a limited oligopoly. The study of the existing oligopoly margins has revealed that it is formed by three leading by their market shares business entities, which cover $68.7 \%$ of the medicinal plantsmarket. In our view, this leads to the risk of collective monopolization of the market, as the oligopolists can reach a dominant supercompetitive position through their coordinated market behavior. The analysis of the dispersion of the oligopoly nucleus, which determines the size ratio of the individual entities that compose it, showed the uneven distribution of market shares between the competing companies. This creates the preconditions for dominance of the largest participants in the market of medicinal plants. This fact in its turn adversely affects the development of competition in this market. In view of this, there is a necessity that the state authorities and the Antimonopoly Committee of Ukraine take these market processes under control. In particular, competitive environment in the medicinal plants market should be monitored and adjusted in order to prevent the strengthening of market power of particular entities and their ability to significantly influence the conditions of market 
circulation of goods. The results of the study will be further used as a basis for the formation of Ukrainianmedicinal plants market strategy development.

\section{References}

1. Ch.P. Kuniyal, P. C. Kuniyal, et al., International Journal of Biodiversity Science, $\begin{array}{llllll}\text { Ecosystem } & \text { Services } & \& & \text { Management } & 9 & \text { (2013) }\end{array}$ https://www.tandfonline.com/doi/full/10.1080/21513732.2013.819531

2. Cultivation and sales of the medicinal plants listed in the Red Book of Ukraine (2019) https://stina.org.ua/wp-content/uploads/2018/05/Vyroshhuvannya-ta-realizatsiyaLikarskyh-trav-zanesenyh-do-CHervonoyi-Knygy-Ukrayiny.pdf

3. O. Drebot, Y. Solohub, Balanced Nature 2, 142-146 (2018)

4. Growing plantain can become more profitable than growing wheat (2019) https://agropolit.com/news/10962-viroschuvati-podorojnik-dlya-agrariyiv-pributkovishe-za-viroschuvannya-pshenitsi

5. L, Hoareau, E. J. DaSilva, Medicinal plants: a re-emerging health aid (2019) http://www.ejbiotechnology.info/content/vol2/issue2/full/2/index.html

6. V. Hornyak, V. Filipovich, Bulletin of ONU Mechnikov 1(16), 14-23 (2012)

7. A. Ivchenko, Flora of Ukraine http://www.photoukraine.com/russian/articles?id=5

8. J. M. Davis, R. E. BirMedicinal, Plants With a Potential Niche Market for Propagators (2019) https://newcropsorganics.ces.ncsu.edu/herb/medicinal-plants-with-a-potentialniche-market-for-propagators

9. D. Lange, Production of medicinal plants in Asia https://www.actahort.org/books/679/679_6.htm

10. T.E. Mafimisebi, The Expanding Market for Herbal, Medicinal and Aromatic Plants In Nigeria and the International Scene (2019) https://www.omicsonline.org/openaccess/the-expanding-market-for-herbal-medicinal-and-aromatic-plants-in-nigeria-andthe-international-scene-2167-0412.1000144.php?aid=21947

11. Medicinal and Aromatic Plants: Trade, Production, and Management of Botanical Resources (2019) https://wwwlib.teiep.gr/images/stories/acta/Acta\%20629/629 25.pdf

12. T. Mirzoieva, Problems of systemic approach in the economy 3(71), 79-85 (2019).

13. Yu. Nykytiuk, Investments: Practice and experience 24, 88-91 (2016)

14. Official site of the State Statistics Service of Ukraine (2019) http://www.ukrstat.gov.ua

15. O. Pervacov, Science and Economics 4(16), 178-181 (2009)

16. T. Pieyeshova, Marketing and management of innovations 4, 113-117 (2011)

17. Phytotherapy Market Research Report - Outlook till 2023 https://www.marketresearchfuture.com/reports/herbal-medicine-market-3250

18. L. Stepanushko, How a company from Dnipropetrovsk revived the cultivation of mintin Ukraine (2019) http://www.dojo.net.ua/?p=1366

19. I.S. Tkachova, Cultivation of medicinal and essential oil cropsis promisingfor the South of Ukraine (2018) http://agro-yug.com.ua/archives/7645

20. R. Ukrepky, O. Migal, Ukrainian Journal of Applied Economics 4, 81-88 (2016)

21. S. Valitov, Yurinkom Inter Kyiv, p. 432 (2006) 
22. V. Volkov, L. Goroshkova, Visnyk of Volyn Economics and Management Institute: Sciences 5, 27-35 (2012)

23. A. Zadoya, Microeconomics: Course of lectures: teach (Znannia, Kyiv, 2010)

24. V. Zalizko, N. Vdovenko, V. Heraimovych, The Common Agricultural Policy of the European Union and the Ways of Its Implementation in Ukraine (2018). The Common Agricultural Policy of the European Union - The Present and the Future, Non-EU Member States Point of View, ed. M. Wigier, A. Kowalski, series "Monographs of Multi-Annual Programme" No 74.1, IAFE-NRI, Warsaw (2018) SSRN: https://ssrn.com/abstract $=3203435$

25. N. Zaytseva, Visnyk SumSU. Series "Economics" 4, 140-146 (2011) 